Quality in Higher Education:

\title{
Student dropout rates in Catalan universities: profile and motives for disengagement
}

\author{
Authors: \\ Gairín, J.- Universitat Autònoma de Barcelona \\ Triadó, X. - Universitat de Barcelona \\ Figuera, P.- Universitat de Barcelona \\ Feixas, M.- Universitat Autònoma de Barcelona \\ Aparicio, P.- Universitat de Barcelona \\ Torrado, M. - Universitat de Barcelona
}

\begin{abstract}
:
Data from over 21,600 students who had left Catalan higher education institutions during the academic years 2000-2001 and 2001-2002 has been analysed in order to describe the academic and personal profiles of university dropouts. Additionally, a telephone survey and face-to-face interviews with a pilot group of leavers were undertaken to gather additional qualitative information on the reasons for their decision. The influences on non-completion can be reduced to three main factors, among which dissatisfaction with the quality of the students' experience, family and work responsibilities, as well as economic difficulties, are prominent.

Analysis conducted showed no significant differences among Catalan higher education institutions, the dropout percentages ranging from $28 \%$ to $33 \%$. These rates should be understood within a context of broad access to higher education. Within the European Higher Education Area (EHEA) scenario, the findings have triggered institutional endeavours to improve the quality of the students' and teachers' experience.
\end{abstract}

\section{Keywords:}

Higher education, student dropout, Catalan university system, motives, disengagement

\section{Introduction}

The Bricall (2000), Attali (1998), Dearing (1997) and Mandelson (2009) reports on the Spanish, French and British educational systems, respectively, brought to light the dropout issue in the nineties as it incided on the effectiveness and efficiency of the university system. They reaffirmed the idea that the phenomenon of university dropout 
rates had to be reduced in order to increase the quality standards and productivity of the institution as well as student satisfaction. Ever since the nineties, the dropout rate has been quantified and used as a performance indicator. Dropout rate has been a widelydiscussed topic by the academic authorities in the European Union, within each country and institution, and has grown with adaptation to the European Higher Education Area (EHEA). However, actions favouring student retention have still not been assessed.

Dropout takes on broader dimensions when extended -almost universally- to access to university studies. Behind this problem lies the economic cost of university studies available to the majority of students and the inefficient use of resources, as well as the problems of dissatisfaction for those who wished to be educated but did not have their expectations fulfilled or have not been properly and professionally oriented towards the type of goals they could hope to fulfil. Undoubtedly, the challenge facing the systems is to maximize the development of a country's human resources through its higher education institutions.

This article addresses the analysis of student dropout rates at public universities in Catalonia (1). The Catalan university system is composed of twelve universities - five of which are private - with a total of 225,181 undergraduate students enrolled - 3,9\% of the population - (AQU, 2007). Worth mentioning is a considerable drop of 7,7\% of new entry students over five consecutive years (2000-2005) caused by demographic factors. According to data for the entire student population of Catalan public universities, during academic year 2004-2005, 76\% of new university students were enrolled in their first choice degree, social sciences being the area with highest enrolments (47\%) and demand (48\%).

More specifically, we aim to investigate the leavers' profile and the factors that may explain or shed new light on what motivates dropout in the Catalan university system. The ultimate goal is to identify strategies for guaranteeing greater student retention rates and success. Data from over 21,600 students who left Catalan higher education institutions during academic years 2000-2001 and 2001-2002 is analysed and contrasted with telephone and face-to-face interviews with dropout students. Beyond the interpretations that can be applied to the dropout rate and the models for analysing it, there are many questions which must be addressed: What do we really know about what goes on in university? Why do students persist? What causes students to drop out? Which of these causes or factors are universities responsible for? How can dropout rates be measured? Is there a more likely student profile favouring dropout? Can an explanatory, integrated model for this phenomenon be found? These are some of the questions that the paper attempts to evidence from the outcomes of interdisciplinary research (2).

[1] Autonomous region of Spain, with its own parliament from 1979 and full educational competences. 7.211 .000 population in 2007 (http://www.idescat.cat). 


\section{Towards a conceptualization of the phenomenon}

A precise, conceptual definition of the university dropout is a complex task that goes beyond the theoretical arena and manifests itself in the policies, actions and studies undertaken by universities and countries all over the world. It is also hard to measure because it requires, not only knowing what it is we wish to measure, but also having suitable and precise institutional data, collected systematically over a certain period of time.

Any bibliographical review displays a huge variation in terminology which hampers comparative studies and definition of the descriptors that must be considered for further analysis. For this reason, the dropout concept and related terms - desertion, stopping, completion, discontinuity, (non-) persistence, survival or retention substantially depend on the context and research objectives devised. It also depends on whether dropping out is to be considered failure or not, as well as on the transition model in which the process is framed.

Longden (2001) synthesized and classified all the terminological casuistry. Of all the terms in use, the most common in the literature in English are dropout, attrition and withdrawal, which in the Catalan context are referred to as abandonament. The utilization of the terms academic failure and dropout or desertion as synonymous is being replaced by a terminology that gives room to the several types of dropout. Thus, Bourdages (1996) brings in the idea of focusing on persistence rather than investigating dropout or non-persistence instead of retention or study continuation.

The National Association of Universities and Higher Education Institutions (ANUIES, 1986) describes dropping out as not attending class and the non-fulfilment of obligations in such a way as to affect the ultimate effectiveness of university degree performance. The dropout rate can also be defined as the percentage number of students in a cohort that have not taken their degree in an established period of time.

Additional research demonstrates that there are problems with students that, whereas they do not drop out, repeat courses, change institution to enrol in the same degree or do not attend courses regularly or take exams. Thus, it is a challenge to find an accurate definition including all possible typologies. With this in mind, we use the following definitions to explain different types of dropouts.

Salvador and García-Valcárcel (1989) describe the dropout student as one who disappears from the university context. García Areito (1986) gives three types of definitions: "non-starters", or those who have never been assessed despite being enrolled for one or two years; real dropouts, referring to students who are examined before leaving the degree, and global dropouts, as the combination of the two aforementioned concepts. For Tinto (1975), dropouts are the flow of students that definitely abandon all forms of university education, or the moment at which students undertake immediate transfer to another institution. Altamira (1997) describes desertion

[2] This project has been financed by the Catalan University Quality Assurance Agency (AQU), a full member of the European Association for Quality Assurance in Higher Education (ENQA) (http://www.aqu.cat/doc/doc_30801544_1.pdf). 
from four points of view: voluntary and definite dropout, by expulsion due to poor academic performance, changing study programs and from disciplinary expulsion.

It is necessary, therefore, to keep in mind the different type of dropouts — voluntary, involuntary, temporary, permanent, initial, provisional, definite, etc. - and the possible relationship (or not) between dropping out and academic failure, or dissatisfaction with the quality of student experience (Yorke, 1998; Yorke \& Longden, 2004). It is also necessary to take into account more precise casuistry, like enrolling for a degree and not sitting examinations, which Himmel (2002) terms «premature baby» or which Giovagnoli (2002) terms «epidemic», when referring to those «absent» students who do not obtain the necessary credits to continue studying, simply because they have stopped going to university.

Operative definitions used since the nineties in the evaluation processes of university quality by the Ministry of Education (Catalogue of Indicators in the Spanish Public University System) (Consejo de Coordinación Universitaria, 2002) associate university dropouts with performance indicators. They have also been used as indicators in higher education institutional rankings (Yorke, 1998). These indicators have evolved parallel with the technological development of universities for gathering and systematizing a whole range of information in their databases. Thus, universities have gone from the simple counting of non-enrolled students to the differentiation of types of dropouts by year and by their obligatory or voluntary nature.

To be able to analyze the dropout phenomenon and to facilitate its calculation, dropout in Spain means students who registered during a course and did not formally enrol again for the next two course periods. In particular, «the dropout indicator registers in a specific course the percentage of students that drop out without academic accreditation, which pertains to the group of registered students in their first course, for the first time, in the different degree courses during the academic year (n-t), (t) being the official duration programmed for each degree at official university centres and (n) in the specific academic course (e.g., 2006-2007), and who have not registered in these degree programs in the two previous courses (2004-2005 and 2005-2006) respectively» (Hernández, 2008, p 522).

\section{Explanatory models of university dropout}

University dropout appears as an object of study in the sixties, and by the seventies a theoretical body refers to the interactionist theory of Vicent Tinto (Berger and Lyon, 2005). Since then, most literature on university study continuity develops along two lines: the Student Integration Model by Spady (1970) and Tinto (1975), and the Student Attrition Model by Bean (1980). Tinto's model has evolved over time and has encouraged the development of an important part of later theoretical models which attempt to comprehend a clearly complex and multidimensional phenomenon.

Among classification models, those of the following stand out: (1) the classification by Braxton, Johnson and Shaw-Sullivan (1997), revised by Himmel (2002) and, recently, by Donoso and Schiefelbein (2007); (2) that of Cabrera et al. (2006); (3) that of Southerland (2006). 
The following table illustrates the coincident and divergent elements of the three classifications of the explanatory models for the university dropout phenomenon.

\section{INSERT TABLE 1 HERE}

Taking the Braxton et al.(1997) classification as reference, the non-persistence analysis approaches can be grouped into five broad categories (psychological, sociological, economic, organizational and integrative) according to the phenomenon's explanatory variables, whether individual, institutional or stemming from the family environment.

More specifically, Tinto's model is based on the fact that academic and social integration explains permanence in the educational system and is influenced, on the one hand, by the student's cultural knowledge on entry, arising from previous academic background, family environment and personal characteristics and, on the other hand, by the initial commitment to the institution and the intention of completing the degree, as well as for positive interactions with the environment (participation in extracurricular activities). Tinto is the first author to insist on several dropout typologies: the voluntary and the involuntary or normative dropout.

Pascarella and Terenzini (1991), extending Tinto's model, consider the factors that directly or indirectly influence student academic performance and the institution's characteristics. Subsequent studies have demonstrated that these factors have a powerful influence on the most minority sectors.

Bean (1983, 1995) adds a psychological perspective: a person's attitudes and behaviour and external factors have a major influence on persistence (family support, family responsibilities, economic resources, etc). This author incorporates the characteristics of the productivity model developed in the context of work organizations into Tinto's model. According to Bean, the following factors have an effect on desertion: (1) academic factors: prior to university, academic integration and academic results; (2) psycho-social factors: goals, perceived utility, interaction with parents and teachers; (3) environmental factors: funding, opportunities to change university, external social relations; (4) socialization factors: academic performance, adaptation and institutional commitment.

Additionally, Bean and Vesper (1990) observed that non-cognitive factors like personal (attitudes, aspirations, motivations, interests), environmental and organizational characteristics, also significantly influence desertion and particularly, voluntary desertion.

In an extension to his original model, Tinto integrates the previous theoretical contributions and transforms them to his current persistence model.

In order to integrate Bean's contributions, Cabrera, Castañeda and Nora (1992), Cabrera, Nora and Castañeda (1993) and St. John et al. (2000) set out a holistic model that entails three phases for the student. In a first phase, academic skills, previous experiences and socio-economic factors influence the decision to continue one's studies. Secondly, the student values the degree's cost-benefit and therefore makes an initial commitment to completing his studies. In the final stage, after entering a degree course, other factors come into play which modify and/or reinforce initial aspirations. 


\section{Methodological approach}

Dropout complexity in higher education, from the point of view of theoretical models and considering the lack of coincidence in assessing the phenomenon in the international context (Feixas, Rodríguez and Gairín, 2010), underline the need to undertake a study in our own university context. This analysis is undertaken in two research phases, with a macro and micro approach:

The first phase analyzes the dropout phenomenon in Catalonia. From the student data collected from the UNEIX platform (3), a descriptive analysis of population has been made, permitting firstly a quantitative approach to the dropout rate and secondly a qualitative one.

The database provided by the Catalan University Quality Assurance Agency (AQU), with the permission of the Directorate-General of Universities of the Generalitat de Catalunya, gathers information on academic year 2005-2006's dropouts for those students that entered university in academic years 2000-2001 and 2001-2002, which reached a total of 21,620 dropouts for the whole Catalan university system.

The following variables are contained in the database provided (Table 2):

\section{INSERT TABLE 2 HERE}

In the second phase, a micro approach from a pilot sample to the specific situation of dropout students in our universities was undertaken through a descriptive and comprehensive study via telephone, and face-to-face, interviews. This has helped to distinguish the reasons why these students gave up their studies and has also gathered feedback to set identifiable retention strategies.

The bibliographical review undertaken has underscored the absence of any standardized system that permits study or awareness of the causes leading a student at any particular moment to decide not to continue his degree. For this reason, a survey "Cuestionario para evaluar el perfil del alumnado universitario que abandona sus estudios” (4) (Gairín, Figuera y Triadó, 2010) and interview protocols were designed. Both include all the theoretical variables that the aforementioned models consider relevant for an explanation of university study dropout. In the data collection phase, this exploratory research, of a descriptive and integral nature, included additional quantitative and qualitative elements from the methodological standpoint.

Table 3 includes the analyzed dimensions and variables of the survey and interview:

\section{INSERT TABLE 3 HERE}

[3] UNEIX is the Portal of the Information System for Universities and Research in Catalonia.

[4] Survey to assess student dropout profile. 
The survey - previously validated by experts - consisted of sixty-five items. Except for the personal and academic data, in most questions the student expressed an opinion on a scale corresponding to a Likert 1 to 10 Scale.

Decisions taken on the sample were related to the data facilitated by AQU Catalonia. The size of the theoretical sample comprised 801 students, the total number of students commencing university studies in 2000-2001. A dropout analysis was performed by degrees and areas and the sample was therefore selected through a proportional stratified sampling taking into account student dropout rates at Catalan public universities and the data on new entry students, to calculate the dropout rates by degrees. Five degrees (one for each area of knowledge) were selected to guarantee a balanced representation across all the sampling variables (degrees, number of students, universities, etc): Business Administration and Management, Biology, Computer Engineering, History and Medicine.

After selecting the degrees, localization and selection of the pilot sample were addressed. The process was as follows:

- Identification and selection of universities: Autonomous University of Barcelona (UAB), University of Barcelona (UB), University of Girona (UdG), Polytechnic University of Catalonia (UPC), Pompeu Fabra University (UPF) and University of Lleida (UdL).

- Institutional request for lists of dropouts in the selected degrees.

- Once available, a random sample was made, taking into account a proportionate distribution by students and degrees.

The effective student sample for telephone survey numbered 275. The response rate was $35.63 \%$ with a global error margin of $+/-5.3 \%$ and a confidence level of $95.5 \%$. The field of study was undertaken during the period September to December 2008.

Before undertaking the telephone surveys, a group of pollsters was hired and trained. This guaranteed one message alone. Internet was also used for data collection because undertaking some telephone surveys proved impossible.

Additionally, in order to go deeper into dropout reasons and complement the survey's information, a series of personal semi-structured interviews averaging an hour in length was undertaken. A sub-sample was taken following the same criteria as with the telephone surveys. All students interviewed were previously polled to gauge their willingness to collaborate. The theoretical sample size was 30 students, but the effective number was 17, interviewed in November and December 2008.

\section{Analysis and discussion of results}

Results are shown for the macro analysis after database examination and the micro analysis focusing on the telephone survey and personal interviews.

Worth mentioning here is the fact that all Catalan universities face a dropout problem, which averages out at 33.6\%. In ranking order, 37\% student dropouts are from 
UPC, followed by the UB, the UAB and, last, the UdL at 28\%, although in relative terms, the higher the enrolment figures, the higher the dropout rate.

Degree choice makes the differences clearer. Dropout rates by degree choice oscillate between $20 \%$ and $60 \%$, and are even higher in certain engineering courses or lower in less traditional studies like physiotherapy.

Degrees vary greatly as to discipline typology, teaching and learning culture, student ratios, facilities, student support, and from satisfaction, motivation and academic quality. While recognizing the wide range between them, some degrees with highest dropout rate are in social sciences (40\%), technology (29.6\%) and arts and humanities (17.2\%).

Over $50 \%$ of students abandon their studies during the first year. This corroborates what other research has shown: the attention necessary to the student's first year's experience. The average period spent by a dropout at university is a little over one and a half years.

The students' profile is informed by different variables which can be grouped into three different moments regarding the students' degree: academic and personal variables, the type of degree the student has abandoned, and university re-entry policy.

1. Students' situation at degree commencement: socio-demographic and social variables and previous academic variables.

Where personal features are concerned, a dropout's socio-demographic profile shows little clear differentiation as to age, gender, parents' studies or employment. Dropout affects the different age groups, more men than women (51.4\% against $48.6 \%$, respectively); and cannot be related to the parents' study level or employment. In this sense, the students' socio-demographic profile is not a determinant factor in the dropout phenomena.

Most of our students drop out during their first year. One possible reason for this situation in Catalonia is that students are transferred to what was a first option rather than the option available on access to university. As to the type of degree, there is a higher dropout percentage in the first university year of technology studies. This invites consideration of the processes and mechanisms of academic promotion that different universities and degrees regulate.

As for academic aspects, the highest numbers of dropouts were students who accessed university from high school and took the Selectivity test (5), while there are fewer dropouts from basic vocational training and higher vocational degrees. Among the former were students from the arts and social sciences Baccalaureate. Another significant percentage is that of students using the entrance examination for those aged 25 and over (14.17\%).

[5] Spanish exam at the end of high school studies that allows access to university. 
2. Variables affecting the degree abandoned, such as academic performance.

Students who drop out usually have a poor academic record: credit points achieved (ECTS) are about 50\% of those required for consideration as a student with optimum academic performance. More particularly, dropouts in technical and experimental science degrees gain fewer ECTS, unlike in health sciences degrees, where students have a better academic record.

3. Ex-post situation, considering the change of degree and university re-entry.

Where re-entering other degree studies in Catalonia is concerned, analysis shows that over $60 \%$ of students who abandoned their studies in 2000-2001 have not reentered the university system. It is likely that a percentage of these students continue their studies outside Catalonia, because a good percentage of them took the Selectivity tests in other Spanish regions. In addition, most students re-entering the university system are those that dropped out of technology and health sciences degrees.

Research limitations are focused on the insufficient indicators or variables in the database to allow us relate dropout causes in a more meaningful way, and the limited possibilities for comparing these data with global enrolment. For these reasons, research conclusions can only underline the overall dropout student profile and outline the percentages and typology of the degrees they dropped out of. It is also of interest to know about re-entry students, although we can only tabulate those re-entering the Catalan university system.

For this reason it was deemed necessary to develop new tools to measure the dropout rate in all its complexity. To this end, we collected additional data linked to: a) other academic variables like learning processes and learning pace, the academic and vocational guidance available, degree motivation, degree evaluation; b) variables affecting the relationship between the student and the institution and the rationale behind his/her dropping out; c) institutional variables like academic support and degree guidance received at university; and d) personal variables like employment, the student's economic situation and socialization factors.

The drafting of two original instruments (a survey and an interview protocol) facilitated this complementary research. On the one hand, the survey approached the profile of those who abandoned their university studies and, on the other hand, the interviews broadened awareness of the circumstances leading to the dropout and its causes.

Results informed us about entry to a university degree program and the fact that students chose their degree mainly for personal interest, based on guidance and support from relatives and peers. Choice of university was usually justified by geographical proximity factors, while aspects such as the prestige and educational policies of each institution were secondary.

Among the reasons for dropping out emerging from the interviews, university leavers pointed out lack of motivation and non-fulfilled expectations. This feature has a direct incidence in academic integration, fundamentally involving a dropping off in class attendance and social activities, and in the attribution of academic success or failure. Moreover, the fact that the decision to leave was mainly recorded during the 
first semester reinforces the importance of retention strategies focused on the first year experience.

Finally, more than half of those who gave up their studies had difficulties reconciling academic activities and employment. The vast majority worked in jobs with little or no connection with the studies. In most cases, dropouts were voluntary.

\section{Concluding remarks}

The OECD's 2009 report sustains that not finishing a university degree does not necessarily mean failure, if the student benefits from the time devoted to the program. OECD annual reports, alongside other aforementioned studies, also alert to high dropout rates and the unavoidable political, economic, social and personal consequences.

Today there is ample access to university studies, yet an important increase in the number of students who abandon their studies is also manifest. It is important to analyze the dropout phenomenon from a geopolitical and sociological standpoint, since different countries define and measure it differently.

In Europe, dropout rates in higher education have increased: more than $30 \%$ of those enrolled do not complete their degree. The survival rate (calculated from the number of graduates and the number of newly-enrolled students) is $71 \%$, and Spain tops this by $3 \%$ (OECD, 2008).

This research attempts to provide an answer - for Catalonia, the rest of Spain and other countries - to these issues, without underestimating the doubts that still emerge from the study's conclusions.

The macro and micro dropout analysis, and therefore, that of the academic persistence in the Catalan university system, has considered as significant variables for influencing dropout: those evident before leaving the course (socio-demographic and academic), as well as the degrees recording highest dropout and the student's situation after leaving university.

The generic analysis demonstrates that since dropout, as a social phenomenon, affects all manner of degrees, there are no significant differences among Catalan universities and slightly less than in Spanish universities (Hernández, 2008). However, we do encounter differences among study programs: the dropout distribution corresponds mainly to social sciences studies, somewhat less to technology studies and affects humanities and health sciences studies to a much lesser degree.

The specific analysis based on the student's profile demonstrates that students are less persistent in their studies due to employment reasons and economic situations. Regarding gender, men are less persistent than women. Social background does not appear to have great influence on dropout rates; however, the high percentage of missing answers in the survey does not enable us to draw definitive conclusions. On the other hand, dropout affects to a greater extent those students who had a lower access grade. Finally, we may state that the dropout rates by degrees fluctuate between $20 \%$ and $60 \%$, but their analysis is very complex due to the enormous variety of degrees taken into account. 
From the analysis of the academic dynamics, in quantitative terms we can ascertain that there is more dropout among students accessing from A-levels and students coming from other autonomous communities; that dropout and low level of academic performance are very correlated; and finally, that more than $60 \%$ of the students who give up their studies do not re-enter the university system.

The macro and micro scale analyses are very indicative but, at the same time, limited by the fact that the available data does not permit the creation of more and better indicators, nor does it allow comparison with the students' global enrolment.

The results of the field study alongside the survey and the interview have made evident the importance of encouraging these types of studies to provide arguments explaining why students do not persist in their studies and the need for a broader sample and holistic set of variables. Dropout motives are diverse and especially rooted in the: a) lack of motivation for the degree and, therefore, in the subsequent difficulty in fully integrating into academic and university life; b) difficulties in reconciling academic life with outside employment; c) lack of economic independence; d) the fact that institutions do not offer interesting programs from the professional and methodological point of view; e) lack of services to support the students' learning and integration process, and f) lack of relevance to the reality of the business and employment world.

The specific histories analysed lead to an understanding of the circumstances accompanying the students' decision to drop out, whether voluntary or imposed. In this sense, the decision to give up their studies focuses on a concrete period of the students' academic life ( $58 \%$ of students who abandon their studies do so in first year). However, the decision to drop out obeys a more complex phenomenon, that is, a set of personal and contextual circumstances that influence the decisions in a significant way.

The study confirms the thesis of the existence of moments of special relevance when facing the decision to drop out and the need to reinforce psycho-pedagogical attention and personal and academic guidance at university, especially during the first year. Problems deriving from a lack of study motivation and performance might also be related with an inadequate degree selection process which forces us to more critical analysis of the guidance processes taking place in post-secondary education.

The flexible organization of the studies and the implantation of modular systems can have a positive impact on student retention rates. Poor motivation behind the degree is also related to the quality of the academic program. Because of this, it is particularly necessary to review educational methodologies and to ensure individual and social activities with a higher impact.

One whole segment of the population exits who should benefit from higher public loans or scholarships. It becomes necessary to put financial constraints to one side as this can have a negative impact on student performance.

Possible re-entry into the university system is also to be considered because interviewees have expressed their willingness to re-enter university again to fulfil their university aspirations. This can be seen as an indicator of satisfaction with the institution's quality. 
Finally, it is well worth mentioning that the Spanish agenda for the implementation of the Bologna reforms has made great efforts to overcome these difficulties and new study plans and university study structures are incorporating retention measures to overcome the aforementioned situations.

\section{References}

Agència per a la Qualitat del Sistema Universitari de Catalunya (AQU) 2007, El sistema universitari públic català 2000-2005: una perspectiva des de l'avaluació d'AQU Catalunya (Barcelona, AQU Catalunya).

Altamira, A., 1997, El análisis de las trayectorias escolares como herramienta de evaluación de la actividad académica universitaria. Un modelo ad hoc para la Universidad Autónoma de Chiapas. Master's thesis in Education. Universidad Autónoma de Chiapas.

Aparicio, P. et al., 2010, 'Anàlisi del fenomen de l'abandonament a Catalunya', in Gairín, J.; Figuera, P. \& Triadó, X., et al., L’abandonament dels estudiants a les universitats catalanes. (Barcelona, AQU Catalunya).

Attali, J. 1998, Por un modèle européen d'enseignement supèrieur (Paris, Rapport de la Commisssion).

ANUIES, 1986, Glosario de la educación superior (México DF, Asociación Nacional de Universidades e Instituciones de Educación Superior).

Bean, J. P., 1983, 'The application of a model of turnover in work organizations to the student attrition process', Review of Higher Education, 6 (2), pp. 129-148.

Bean, J. P. 1995, 'An approach/avoidance behavioral model of college student attrition', Research in Higher Education, 36, 6, pp. 617-645.

Bean,J.; Vesper, N. 1990, Quantitative Approaches to Grounding Theory in Data: Using LISREL to Develop a Local Model and Theory of Student Attrition. (Annual Meeting AERA, Boston, Mass.)

Berger, J. B.; Lyon, S. C., 2005, 'Past to present: A historical look at retention’, in Seidman, A. [ed.]. College Student Retention: Formula for Student Success. (London, Greenwood Publishing Group).

Bourdages, L., 1996, 'La persistance et la no-persistance aux études universitaires sur campus et en formation à distance’, DistanceS, 1 (1), pp. 51-67.

Braxton, J. M.; Johnson, R. M.; Shaw-Sullivan, A., 1997, ‘Appraising Tinto’s theory of college student departure', in: Smart, J. C. [ed.]. Higher Education: A Handbook of Theory and Research, Vol. 12, p. 107-164 (New York, Agathon Press).

Bricall, J.M, 2000, Universidad 2000. Informe sobre la enseñanza superior en España. (Madrid, Conferencia de Rectores de la Universidades Españolas).

Cabrera, A. F.; Castañeda, M. B.; Nora, A., 1992, 'The role of finances in the persistence process: A structural model'. Research in Higher Education, 33, 5, pp. 143164. 
Cabrera, A. F.; Nora, A.; Castañeda, M. B., 1993, 'College persistence: Structural equations modeling test of an integrated model of student retention'. Journal of Higher Education, 64, 2, 123-139.

Cabrera L.; Bethencourt J. T.; Álvarez P.; González M., 2006, ‘El problema del abandono en los estudios universitarios'. RELIEVE, 12, 171-203.

Consejo de Coordinación Universitaria, 2002, Catálogo de Indicadores del Sistema Universitario Público Español (Madrid, MEC).

Dearing, R, 1997, Higher education in the learning society. (London. The National Committee of Inquiry into Higher Educations, HMSO).

Donoso, S. \& Schiefelbein, E., 2007, 'Análisis de los modelos explicativos de retención de estudiantes en la universidad: una visión desde la desigualdad social’. Estudios Pedagógicos, vol. XXXIII (1) 7-27.

Feixas, M.; Rodríguez, D. \& Gairín, J., 2010, 'Panorama internacional i nacional de l'abandonament a la universitat', in Gairín, J.; Figuera, P. \& Triadó, X., et al., L'abandonament dels estudiants a les universitats catalanes. (Barcelona, AQU Catalunya).

Gairín, J.; Figuera, P. \& Triadó, X., et al. 2010, L’abandonament dels estudiants a les universitats catalanes. (Barcelona, AQU Catalunya).

García Areito, L., 1986, Análisis de la eficacia de la educación superior a distancia en Extremadura. Doctoral thesis. Universidad Nacional de Educación Distancia, Madrid.

Giovagnoli, P. I. 2002, Determinantes de la deserción y graduación universitaria: una aplicación utilizando modelos de duración. Doctoral thesis. Universidad La Pampa, Argentina.

Hernández, J. [dir.], 2008, La universidad española en cifras. (Madrid, Conferencia de Rectores de las Universidades Españolas). <http://www.boe.es/boe/dias/2008/06/30/pdfs/A28877-28880.pdf> [Accessed 3 July 2008].

Himmel, E., 2002, 'Modelos de análisis de la deserción estudiantil en la educación superior’. Calidad de la Educación, 17, pp. 91-108.

Longden, B. (2001). 'Off course - Renewed interest in retention but whose interest is being served?' (Higher Education Close Up Conference 2, Lancaster University, 16-18 July 2001) <http://www.leeds.ac.uk/educol/documents/00001766.htm> [Accessed 10 July 2009]

Mandelson, P., 2009, Higher Ambitions: The future of universities in a knowledge economy. (Department for Business, Innovation \& Skills, UK).

OECD, 2009, Education at a glance. <http://www.oecd.org/edu/eag2009 [Accessed 6 May 2010]

OECD, 2008, Education at a glance. <http://www.oecd.org/edu/eag2008 [Accessed 29 April 2009] 
Pascarella, E. T.; Terenzini, P. T. ,1991, How College Affects Students (San Francisco, Jossey-Bass).

Salvador, L. \& García-Valcárcel, A. M., 1989, El rendimiento académico en la Universidad de Cantabria: abandono y retraso en los estudios (Madrid, CIDE).

Southerland, J. N., 2006, Formulating a New Model of College Choice and Persistence (ASHE Annual Conference. 3 November 2006).

St. John, E. P., Cabrera, A.F., Nora, A. \& Asker, E.H., 2000, 'Economic influences on persistence', in Braxton, J. M. Reworking the student departure puzzle: New theory and research on college student retention. (Nashville, Vanderbilt University Press).

Spady, W. G. ,1970, 'Dropout from higher education: An interdisciplinary review and synthesis’, Interchange, 1 (1) pp. 64-85.

Tinto, V., 1975, 'Dropout from higher education: A theoretical synthesis of recent research’ Review of Educational Research, 45, 1, pp. 89-125.

Torrado, M. et al. 2010, 'Models explicatius i factors associats a l'abandonament universitari', in Gairín, J.; Figuera, P. \& Triadó, X., et al., L'abandonament dels estudiants a les universitats catalanes. (Barcelona, AQU Catalunya).

Yorke, M., 1998, 'Non-completion of undergraduate study: some implications for policy in higher education', Journal of Higher Education Policy and Management, 20, 2, pp. 189-201.

Yorke, M.; Longden, B., 2004, Retention and Student Success in Higher Education. (Maidenhead, United Kingdom, Open University Press). 


\section{TABLES:}

Table 1.Convergent and divergent elements of three dropout model classifications (Torrado et al., 2010: 17).

\begin{tabular}{|l|l|l|l|l|}
\hline Models & Definitions & $\begin{array}{l}\text { Braxton } \\
\text { et al. }\end{array}$ & $\begin{array}{l}\text { Cabrera } \\
\text { et al. }\end{array}$ & Sutherland \\
\hline Psychological & $\begin{array}{l}\text { Personal student characteristics (personality, } \\
\text { motivation, personal development...). }\end{array}$ & $\mathrm{X}$ & $\mathrm{X}$ \\
\hline Sociological & $\begin{array}{l}\text { External student characteristics (class, } \\
\text { university prestige...). }\end{array}$ & $\mathrm{X}$ & $\mathrm{X}$ \\
\hline Economic & Cost-benefit assumed. & $\mathrm{X}$ & $\mathrm{X}$ & $\mathrm{X}$ \\
\hline Organizational & Institution (resources, services, structure...). & $\mathrm{X}$ & $\mathrm{X}$ & $\mathrm{X}$ \\
\hline $\begin{array}{l}\text { Psycho- } \\
\text { pedagogical }\end{array}$ & $\begin{array}{l}\text { Dropout considered from a global perspective } \\
\text { including psycho-pedagogical dimensions } \\
\text { (learning styles, lecturing staff quality...). }\end{array}$ & $\mathrm{X}$ & \\
\hline Others & $\begin{array}{l}\text { ADAPTATION: student's social and } \\
\text { academic integration } \\
\text { STRUCTURE: contradictions of the different } \\
\text { subsystems (political, economic and social). }\end{array}$ & $\mathrm{X}$ & & \\
\hline
\end{tabular}

Table2. Student profile variables (Aparicio et. al., 2010:64)

\begin{tabular}{|l|l|}
\hline Dimensions & Variables \\
\hline Before dropout (ex ante) \\
\hline $\begin{array}{l}\text { Student's socio-demographic } \\
\text { and social variables }\end{array}$ & Age \\
& Gender \\
& $\begin{array}{l}\text { Nationality } \\
\text { Studies } \\
\text { Employment }\end{array}$ \\
\hline $\begin{array}{l}\text { Academic variables prior to } \\
\text { university entry }\end{array}$ & $\begin{array}{l}\text { Access modality } \\
\text { Access grade }\end{array}$ \\
\hline Degree program that has been dropped-out \\
\hline $\begin{array}{l}\text { Variables of the study program } \\
\text { that has been dropped-out }\end{array}$ & $\begin{array}{l}\text { Study program area } \\
\text { Required access grade } \\
\text { University }\end{array}$ \\
\hline $\begin{array}{l}\text { Performance in the degree } \\
\text { program }\end{array}$ & Accumulated passed credits \\
& Number of years \\
& Average of passed credits/year before the dropout \\
& Enrolled credits in the dropout year \\
\hline After the dropout (ex post) & $\begin{array}{l}\text { Re-entry study program } \\
\text { Re-entry year } \\
\text { Post-dropout situation } \\
\end{array}$
\end{tabular}


Table 3. Survey and interview dimensions and variables (Aparicio et al. 2010: 89-90).

\begin{tabular}{|c|c|c|c|}
\hline MOMENT & DIMENSIONS & SURVEY VARIABLES & INTERVIEW INFORMATION \\
\hline \multirow{3}{*}{$\begin{array}{l}\text { Pre-drop- } \\
\text { out } \\
\text { aspects } \\
\text { (EX } \\
\text { ANTE) }\end{array}$} & $\begin{array}{l}\text { Basic personal } \\
\text { and family } \\
\text { background }\end{array}$ & $\begin{array}{l}\text { Personal: gender, age, marital } \\
\text { status } \\
\text { Family: studies and parents' } \\
\text { employment }\end{array}$ & \multirow{3}{*}{$\begin{array}{l}\text { Information and activities } \\
\text { linked to university choice } \\
\text { Effective guidance for } \\
\text { university access } \\
\text { Reasons behind university } \\
\text { and study program choice }\end{array}$} \\
\hline & $\begin{array}{l}\text { Academic } \\
\text { background }\end{array}$ & $\begin{array}{l}\text { Secondary school profile } \\
\text { (public, private), access } \\
\text { system, average grade }\end{array}$ & \\
\hline & Motivations & $\begin{array}{l}\text { Degree preference, guidance, } \\
\text { criteria for degree choice } \\
\text { (academic, occupational, } \\
\text { others) }\end{array}$ & \\
\hline \multirow[t]{5}{*}{$\begin{array}{l}\text { During } \\
\text { studies }\end{array}$} & Academic data & $\begin{array}{l}\text { Study program, university, } \\
\text { course and group }\end{array}$ & \multirow{8}{*}{$\begin{array}{l}\text { University study expectation } \\
\text { Useful aids offered by } \\
\text { university } \\
\text { Difficulties leading to } \\
\text { dropout } \\
\text { Hindrances to studying } \\
\text { External university reasons } \\
\text { contributing to degree } \\
\text { dropout }\end{array}$} \\
\hline & Economic data & $\begin{array}{l}\text { Type of financing: self- } \\
\text { financed, scholarships, work }\end{array}$ & \\
\hline & $\begin{array}{l}\text { Academic } \\
\text { integration }\end{array}$ & $\begin{array}{l}\text { Study dedication: student } \\
\text { characteristics about learning } \\
\text { style and attitudes, motives for } \\
\text { attendance/non-attendance, } \\
\text { hours of study } \\
\text { Motivations: satisfaction with } \\
\text { initial expectations, perception } \\
\text { of utility, motivation to finish. } \\
\text { Integration into academic life }\end{array}$ & \\
\hline & $\begin{array}{l}\text { Social } \\
\text { integration }\end{array}$ & Peer, social activities & \\
\hline & Satisfaction & $\begin{array}{l}\text { Academic dimensions: courses } \\
\text { taken, teachers, teaching and } \\
\text { curriculum quality. } \\
\text { Campus services }\end{array}$ & \\
\hline \multirow{3}{*}{$\begin{array}{l}\text { At the } \\
\text { drop-out } \\
\text { moment }\end{array}$} & $\begin{array}{l}\text { Personal } \\
\text { situation }\end{array}$ & $\begin{array}{l}\text { Age, family situation, work } \\
\text { situation }\end{array}$ & \\
\hline & $\begin{array}{l}\text { Academic } \\
\text { situation }\end{array}$ & $\begin{array}{l}\text { Course, semester and group } \\
\text { Number of years, number of } \\
\text { credits passed }\end{array}$ & \\
\hline & Motivations & Main drop-out motives & \\
\hline \multirow{3}{*}{$\begin{array}{l}\text { Post- } \\
\text { drop-out } \\
\text { aspects } \\
\text { (EX } \\
\text { POST) }\end{array}$} & $\begin{array}{l}\text { Employment } \\
\text { situation }\end{array}$ & Employment situation & \multirow{3}{*}{$\begin{array}{l}\text { Aids and resources needed to } \\
\text { continue studies } \\
\text { Ideas for improving the study } \\
\text { program and the teaching and } \\
\text { learning process } \\
\text { Conditions under which } \\
\text { would return to university }\end{array}$} \\
\hline & $\begin{array}{l}\text { Academic } \\
\text { situation }\end{array}$ & $\begin{array}{l}\text { Degree continuation, type of } \\
\text { studies, university }\end{array}$ & \\
\hline & $\begin{array}{l}\text { Re-entry } \\
\text { intentions }\end{array}$ & Motives & \\
\hline
\end{tabular}


